\title{
MAINTAINING THE HIGH DIVERSITY OF PINE AND OAK SPECIES IN MEXICAN TEMPERATE FORESTS: A NEW MANAGEMENT APPROACH COMBINING FUNCTIONAL ZONING AND ECOSYSTEM ADAPTABILITY
}

\begin{tabular}{|r|l|}
\hline Journal: & Canadian Journal of Forest Research \\
\hline Manuscript ID: & cjfr-2014-0561.R1 \\
\hline Manuscript Type: & Article \\
\hline Date Submitted by the Author: & 04-Apr-2015 \\
\hline Complete List of Authors: & $\begin{array}{l}\text { Galicia Sarmiento, Leopoldo; Instituto de Geografia- UNAM, } \\
\text { Potvin, Catherine; McGill University, Department of Biology } \\
\text { Messier, Christian; Université du Québec à Montréal, Department of } \\
\text { Biological Sciences }\end{array}$ \\
\hline Keyword: & Adaptability, Biodiversity, Climate change, Disturbances, Fire regime \\
\hline
\end{tabular}

\section{SCHOLARONE \\ Manuscripts}



MAINTAINING THE HIGH DIVERSITY OF PINE AND OAK SPECIES IN MEXICAN TEMPERATE FORESTS: A NEW MANAGEMENT APPROACH Leopoldo Galicia ${ }^{1}$, Catherine Potvin ${ }^{2,3}$ \& Christian Messier ${ }^{4}$

${ }^{2}$ Department of Biology, McGill University, Canada, Stewart Biology Building, 1205

${ }^{1}$ Instituto de Geografía, Universidad Nacional Autónoma de México Circuito Exterior s/n, Ciudad Universitaria, 04510, México D. F., Mexico 1 3 4 Doctor Penfield, Montreal, Québec, Canada H3A 1B1 and

${ }^{3}$ Smithsonian Tropical Research Institute, Panamá, Republic of Panama 5

${ }^{4}$ Université du Québec à Montréal, Canada, Case postale 8888, Succursale Centre17 Ville, Montréal (Québec) H3C 3P8 and Université du Québec en Outaouais, Gatineau, 8 Canada 


\section{Abstract}

21 Mexican temperate forests, at the southernmost end of the distribution range of this 22 ecosystem, are the world centre of diversity of pine and oak with 55 and 161 species, 23 respectively. Such forests are threatened by land-use change, unsustainable forest 24 management practices and climate change; these threats reduce their diversity, alter the 25 distribution ranges of species, modify disturbance regimes and reduce ecosystem 26 adaptability. This paper briefly reviews (1) the ecology of the Mexican temperate forests,

27 (2) the ecological basis for the unique diversity of pine and oak species, (3) the main 28 disturbances as well as the main drivers of global changes affecting these forests, in 29 particular climate change, and (4) the social, economic and cultural factors to be considered 30 in proposing a new forest management approach. It proposes a new conceptual framework 31 to manage Mexican temperate forests that are in line with (1) their natural dynamics, (2) the 32 rapidly changing and uncertain global environmental, social and economic conditions, and 33 (3) the complex-adaptive-system approach. This new forest management combines 34 functional zoning, multi-species plantations and sylvicultural interventions to increase the 35 adaptive capacity of forests as a way to balance the increasing need for timber products 36 with the need for other ecosystem services facing rapidly changing and uncertain future 37 environmental, social and economic conditions.

39 Key words: Adaptability; Biodiversity; Climate change; Disturbances; Fire regime; Forest 40 income. 


\section{Résumé}

43 Les forêts tempérées mexicaines, situées à l'extrême sud de l'aire de répartition de cet

44 écosystème, sont le centre mondial de la diversité de pins et de chênes comptant 55 et 161

45 espèces, respectivement. Ces forêts sont menacées par la façon dont elles sont utilisées, par

46 des pratiques de gestion de forêts non durable et dû au changement climatique; ces menaces

47 réduisent leur diversité, modifient les aires de répartition des espèces, modifient les régimes

48 de perturbations et réduisent l'adaptabilité de l'écosystème. Cet article examine brièvement

49 (1) l'écologie des forêts tempérées mexicaines, (2) la base écologique de la diversité unique

50 d'espèces de pins et de chênes, (3) les principales perturbations ainsi que les principaux

51 moteurs des changements globaux qui affectent ces forêts, en particulier le changement

52 climatique, et (4) les facteurs sociaux, économiques et culturels, à prendre en considération,

53 en proposant une nouvelle approche de la gestion forestière. Cet article propose un nouveau

54 cadre conceptuel pour gérer les forêts tempérées mexicaines conforme avec (1) leur

55 dynamique naturelle, (2) les conditions environnementales, sociales et économiques

56 globales, en changement continuel et incertaines, et (3) l'approche adaptative du système

57 complexe. Cette nouvelle gestion forestière combine un zonage fonctionnel, des plantations

58 multi-espèces et des interventions sylvicoles pour augmenter la capacité d'adaptation des

59 forêts afin d'équilibrer la nécessité croissante des produits forestiers avec la nécessité de

60 d'autres services écosystémiques exposés à des conditions environnementales, sociales et

61 économiques qui sont en changement continuel et incertaines. 

Mexican temperate forests

64 Mexican temperate forest ecosystems include single-species or mixed forests of pine (Pinus 65 spp.), oak (Quercus spp.) and many other genera such as Abies, Pseudotsuga, Picea, 66 Cupressus and Juniperus and species of more specific origin (Arbutus xalapensis, Alnus 67 firmifolia, Prunus capuli) or restricted distribution (Pinus hartwegii), and endemics 68 (Crataegus mexicana) (Figure 1) (Perry 1991; Farjon and Styles 1997). Three subgenera of 69 the genus Quercus occur in Mexico: Erythrobalanus (white oaks); Lobatae (red oaks); and 70 Protobalanus (intermediate oaks). Mexican temperate forests also harbour about 656 71 species of amphibians, 1,300 species of birds, 1,586 species of reptiles and 146 species of 72 mammals; many of them are restricted to temperate forest habitats (Challenger 1998; 73 Ceballos et al. 2002). While pine (Pinus spp.) and oak (Quercus spp.) forests are widely distributed 75 throughout the Northern hemisphere (North America, Europe and Asia), reaching farther south to Central America (Richardson et al. 2007), Mexico is recognized as the major

77 diversity centre for both genera. Of the 110 pine species and 450 oak species known 78 worldwide, some 46 and 170 species, respectively, are indigenous to Mexico, making this 79 country the major diversity and evolutionary centre for pine and oak species in the 80 American continent (Perry 1991; Rzedowski 1993; Farjon and Styles 1997; Zavala-Chávez 81 2007). It is estimated that some 24 pine species and 109 oak species are endemic to 82 Mexico; this represents $55 \%$ and $68 \%$ of the world's pine and oak endemic species, 83 respectively (Rzedowski 1978; Perry 1991; Farjon and Styles 1997; Zavala-Chávez 2007).

84 By contrast, the USA and Canada together harbour 87 oak species, 52 of which are also 
85 found in Mexico. Canada and the USA are home to 9 and 25 pine species, respectively, 86 while Mexico harbours 21 and 45 pine species not shared with the USA or Canada, 87 respectively (Richardson et al. 2007).

Mexican temperate forests host many commercially valuable timber species (FAO 2010). Pine and oak species accounted for $78 \%$ and $10 \%$, respectively, of the country's timber production during the period 2000 - 2010 (Comisión Nacional Forestal or CONAFOR 2012). Pine timber is mainly used for planks and furniture, whereas oak timber

92 is used primarily for construction work, charcoal production, local handcrafts and furniture (CONAFOR 2012). Pine and oak forests also sustain community forestry, providing timber and non-timber forest products and services (Bray and Merino 2005) including materials (wood, fibre and food), energy resources (firewood) and a number of ecosystem services such as groundwater recharge, climate regulation and lessening of land degradation (Galicia and Zarco-Arista 2014). However, only about $12 \%$ of these forest communities are subject to environmentally sound management according to CONAFOR. Community forestry in

99 Mexico must adopt a more holistic approach in developing a forestry program as proposed by CONAFOR (2012). CONAFOR in its proposal to the National Strategy for Sustainable

101 Forest Management for Increasing Production and Productivity 2013-2018 (ENAIPROS)

102 and the 2025 Strategic Forest Program (PEF 2025) considers that sustainable forest 103 management in Mexico must harness and increase the productivity of forest ecosystems 104 through improved sylvicultural practices but must also recognize and generate alternatives

105 for other benefits (biodiversity conservation, maintenance of water and soil contribution to 106 the global carbon cycle, and multiple socioeconomic benefits). This is to be ensured 107 through regulation, incentives, financing and other policy instruments to achieve the goal of 
108

109

110

111

112

113

114

115

116

117

sustainable forest management. Mexican temperate forests have received little attention in theoretical reviews of forest resources, forest ecology and global climate-change models at a regional level (Bréda et al. 2006; Gómez-Mendoza and Arriaga 2007; Richardson et al. 2007; Gómez-Díaz et al. 2011). Autoecological studies in Mexican temperate forests are also scarce (Eguiluz-Piedra 1985; Farjon and Styles 1997). In fact, forestry research in Mexico has focused primarily on estimating wood volume and timber extraction (Bray and Merino 2005), with little information on forest ecology and the panoply of environmental goods and services provided by forests (Galicia and Zarco-Arista 2014). The present review

focuses on describing the interactions between ecosystem processes, species distribution and diversity of mainly oak and pine species and the dynamics of natural (wind and fire) and anthropogenic disturbances (timber harvest and climate change). It serves as a basis for proposing a new forest management approach that is compatible with natural processes, the rapidly changing and uncertain social, economic and environmental conditions and action plans to prevent further degradation of these ecosystems in Mexico.

\section{Ecological basis for this high biological diversity of oaks and pines and conservation} status

Geological and paleo-climatic evidence suggests that natural barriers to gene flow, and naturally induced climate change in the past together explain the high number of pine and oak species that coexist today in Mexico (Farjon and Styles 1997; González-Rodríguez et al. 2004). For pines, occasional shelters during glacial periods allowed the conservation of many species that expanded their distribution during interglacial periods of re-colonization 
130 (Eguiluz 1982; Perry 1991; Rzedowski 1993; Farjon and Styles 1997). The high species

131 richness of the genus Pinus can be explained by the existence of two diversification centres:

132 (1) in the Trans-Mexican Neovolcanic Belt, that bore three polymorphic species $(P$.

133 devoniana, P. montezumae and P. pseudostrobus) which have further radiated throughout 134 many mountainous regions in Mexico; and (2) in north-eastern Mexico, characterized by 135 adaptations to arid conditions, formation of mountain islands and local endemism (Figure 136 1) (Eguiluz-Piedra 1985; Rzedowski 1993; Farjon and Styles 1997). The Sierra Madre 137 Occidental (stretches from the Sonora-Arizona border to the Tran-volcanic belt) is 138 particularly rich in diversity since it has the country's largest area of temperate forests, and 139 a wide variety of habitats. There are 24 species of pine (46\% of the national total) and 54 140 oak (34\%) (González-Elizondo et al. 2012). In the case of the genus Pinus, the 141 diversification centres, along with migration processes resulted in five distinct regions that 142 differ in endemism, species richness, composition, diversity and ecology (Figure 1). Unlike 143 the wide distribution ranges and low diversity of pine and oak species in boreal regions 144 (Farjon 1990; Farjon and Styles 1997), in Mexico these species are broadly distributed with 145 distinct ecological ranges. Pine species are found at elevations ranging from $100 \mathrm{~m}$ a.s.l. $(P$. 146 caribaea) to over 4,000 m a.s.1. (P. hartwegii); and annual rainfall that ranges from $200 \mathrm{~mm}$ 147 (P. lambertiana) to $2500 \mathrm{~mm}$ (P. pinceana) (Figure 2). At local and regional scales, the 148 structure and composition of vegetation is determined by local environmental 149 characteristics such as geologic substratum, soil type, elevation, topography and 150 microclimate conditions, soil fertility and quality, humidity and temperature (Eguiluz151 Piedra 1985; Challenger 1998; Sánchez-González 2008). 
153 species such as $P$. patula, $P$. oocarpa, $P$. greggii, $P$. pinceana, $P$. leiophylla, Pseudotsuga

154 menziesii and Cedrela odorata (Aguirre-Planter et al. 2000; Molina-Freaner et al. 2001;

155 Parraguirre-Lezama et al. 2002; Dvorak et al. 2009; Rodríguez-Banderas et al. 2009). These 156 studies highlighted the high genetic diversity of Mexican pine species (Farjon and Styles

157 1997; Delgado et al. 2007; Moreno-Letelier and Piñero 2009). Delgado et al. (1999) 158 suggest that most conifers have high levels of genetic variation and relatively little genetic 159 differentiation among populations. The principal explanation for the low genetic 160 differentiation found in conifer species is based on the reproductive systems particular to 161 this group (seed and pollen are wind dispersed and this allows a more efficient gene flow 162 among distant populations). However, this pattern can be modified by other factors, such as 163 environmental fluctuations and micro-spatial habitat selection. diversity due to its out-crossing breeding system and an intense gene flow between 166 populations (Rodríguez-Banderas et al. 2009). It has also been reported that two P. radiata 167 populations growing in contrasting environments displayed the same level of genetic 168 variability but differed significantly from each other (Moran et al. 1998). Molina-Freaner et 169 al. (2001) reported that $P$. pinceana, $P$. laguanae and $P$. muricata are rare species with high 170 levels of genetic variability, as indicated by their high heterozygosity and high between171 population differentiation. This has favoured selection of high-yielding genotypes for 172 commercial plantations and reforestation programs in Mexico and other countries (Molina173 Freaner et al. 2001). Sánchez-Velásquez et al. (2009) suggested that $P$. maximinoi and $P$. 174 patula might be useful for restoration works in mountainous areas whereas exotic species 
175 such as $P$. sylvestris and $P$. radiata var. binata can serve as nurse plants to facilitate the 176 regeneration of other natural pine species. Owing to its rapid growth and good adaptation to 177 different environments Pinus greggii has been widely used in reforestation. These 178 differences among species may be associated with adaptation to different degree of 179 variation between and within provenances or populations, including variations in growth 180 relative to soil $\mathrm{pH}$ (Ramírez-Herrera et al. 2005). For example, in order to determine the 181 degree of genetic isolation between populations the southern stands (Puebla, Hidalgo and 182 Querétaro) grow at lower elevations, with higher mean annual temperature and 183 precipitation $\left( \pm 1.720 \mathrm{~m}, \pm 17.5^{\circ} \mathrm{C}\right.$ and $\left.\pm 1.370 \mathrm{~mm}\right)$ than the populations of the northern 184 region (Coahuila and Nuevo Leon) $\left( \pm 2.450 \mathrm{~m}, \pm 13^{\circ} \mathrm{C}\right.$ and $\pm 640 \mathrm{~mm}$ ) (Ramírez-Herrera 185 et al. 2005).

In America, the genus Quercus is distributed from southern Canada to Colombia.

187 Geological history has created specific discontinuities due to climate changes and gene 188 barriers (Nixon 1993). During the most recent glacial period in North America, some 12 189000 years ago, oak species migrated northward. As a result, closely related species are now 190 commonly found in geographically separated regions (Sauer 1988; Zavala-Chávez 1998) 191 (Table 1). In temperate regions, colder temperatures during glacial periods may have 192 caused population decline because many oaks that do not undergo winter dormancy have 193 limited cold tolerance (Cavender-Bares et al 2011). Fragmentation and isolation of 194 populations, along with limited gene flow, would have naturally followed. In contrast, less 195 drastic changes in climate may have limited such impacts in Central America (Cavender196 Bares et al. 2010). In Mexico, oak species grow in temperate and tropical zones but the 197 highest species richness is found in temperate zones, particularly in the central and southern 
198 parts of the country where up to 75 oak species occur (Challenger 1998); it is in these 199 regions and the Sierra Madre Oriental that the largest number of pine species also occurs. 200 Oak forests are widely distributed in Mexican mountain ranges, covering approximately $2015.5 \%$ of the country's surface area (Challenger 1998). The highest diversity of oak species, $20295 \%$ of the known Mexican species, occurs at elevations ranging between 1,200 and 2,800 $203 \mathrm{~m}$, although oak species can be found from 200 to 3,500 m (Figure 2). White oaks are 204 widely distributed in the north-eastern zone, while red oaks mostly occur in western and 205 southern Mexico (Nixon 1998; Zavala-Chávez 1998; Valencia 2004). The oak genus 206 displays a remarkable floristic, physiognomic and ecological diversity including entirely 207 deciduous and fully evergreen species. For example, Q. laceyi, a medium-stature tree, ranging from 3-8 $\mathrm{m}$ in height,

209 typically colonizes hot, dry sites and is both the lowest-ranging tree species growing in 210 Sierra del Carmen, Coahuila, Mexico, and the dominant low-elevation oak in savannahs 211 and riparian areas. Q. sideroxyla is the dominant high-elevation oak in Sierra del Carmen 212 (Nixon 1998; Valencia 2004). Genetic diversity, as assessed by nuclear microsatellites, is 213 higher in the tropical species $Q$. oleoides than in the temperate $Q$. virginiana, but neutral 214 genetic differentiation between populations is higher in the latter (Cavender-Bares et al. 215 2011). In addition, oak species are morphologically highly variable, display a high 216 phenotypic plasticity, and have great potential for hybridization and genetic introgression 217 (Cavender-Bares 2008). However, no conservation strategies for gene banks exist in 218 Mexico (Cavender-Bares 2007, Cavender-Bares et al. 2011). 
Finally, pine and oak forests are the ecosystems least represented in protected areas in Mexico, far below the $12 \%$ recommended by some authors (Conabio 2007) (Conabio

221 stands for: The National Commission for Knowledge and Use of Biodiversity 222 Commission). Arriaga-Cabrera et al. (2009) estimated that protected areas cover $<5 \%$ of 223 the temperate forests with only $5.9 \%, 5.4 \%$ and $4.6 \%$ of the pine, oak and pine-oak forests 224 being protected, respectively. However, the oak-pine forests have a higher percentage of 225 protection with $7.1 \%$. Temperate forest protection should be increased because together oak 226 forest represents high beta diversity for the country. On the other hand, Aguirre-Gutiérrez 227 and Duivenvoorden (2010) concluded that, while high-elevation species (e.g. P. hartwegii) 228 are well represented in protected areas, low-elevation species (P. attenuata, P. cembroides 229 subsp. cembroides, $P$. radiata var. binata, $P$. rzedowskii and $P$. muricata) are poorly 230 represented in these areas. It has been suggested that efforts should be made to protect pine 231 species growing in the Sierra Madre Occidental and Sierra Madre del Sur. Delgado et al. 232 (2008) have suggested on the basis of phylogenetic, genetic and demographic data that they 233 should also be protected in Baja California.

\section{Stand dynamics and disturbance impacts}

236 In Mexico, some 1,582,040 ha of temperate forest and tropical were burnt in the 1970s, $2372,579,760$ ha in the 1980 s and 2,516,979 ha in the 1990s. Within that period, the year 1998 238 -an ENSO year- was particularly dramatic, with 14445 wildfires recorded and 850000 ha 239 affected (CONAFOR, 2008); and the year 2011 had 12061 wildfires recorded and 954946 240 ha affected. The role that wildfire played in structuring the pine and oak forests of Mexico 
241 has been discussed but no consensus as to its importance has been reached (Table 2)

242 (Rzedowski 1993; Fulé and Covington 1996; Fulé and Covington 1998; González-Rosales

243 and Rodríguez-Trejo 2004; González-Tagle et al. 2008; Rodríguez-Trejo 2008). For

244 example, Rzedowski (1993) does not regard wildfires as an integral part of the forest's

245 natural dynamics because they are mostly the result of grassland management and

246 agricultural practices. Indeed, wildfires are often associated with land use intensity, as

247 shown by a relationship between their highest frequency of occurrence and the agricultural

248 calendar (CONAFOR 2008; Manzo-Delgado et al. 2009; Ávila-Flores 2010; Yocom and

249 Fulé 2012). On the other hand, Fulé and Covington (1998), Rodríguez-Trejo and Fulé

250 (2003) and Richardson et al. (2007) regard wildfire as an integral part of the structure,

251 functioning and regeneration pattern of temperate and boreal forests, because it promotes

252 organic matter recycling and species succession, and creates a mosaic of environmental

253 conditions that fosters ecosystem diversity and stability. However, pine and oak species

254 differ in their response to forest fire (Table 3), particularly in terms of their regeneration

255 from seed; in some species of pine with serotinous cones, fire favours recruitment, whereas

256 in oak species it reduces seed viability. Some pine and oak species are characterized by

257 frequent non-lethal fires, but a few pine and oak species persist in areas characterized by

258 lethal crown fires. Mexico has established fire-management / fire-exclusion policy to

259 encompass any type of fire management strategy, including fire suppression (Fulé and

260 Covington 1994; Fulé and Covington 1999; Rodríguez-Trejo and Myers 2010). Information

261 on fire adaptation in oak and pine species is limited and based on inferences about climate,

262 growth form, vegetative regeneration, and regeneration niche (Rodríguez-Trejo and Fulé

263 2003, Rodríguez-Trejo and Myers 2010). In contrast, drought or delays of rainfall in other 
264 places have led to a rise in wildfire intensity and hence have promoted the expansion of the 265 distribution ranges of some species and the local extinction of others (Richardson et al. 266 2007). The debate now is not if but how anthropogenic vs. climate driven fires affect forest 267 structure given that forests natural or historic fire regime. 269 functioning of pine and oak is probably due to the wide spatial heterogeneity in the 270 distribution, presence and intensity of fires, and in the biology/ecology of the species 271 (Table 2). For example, the frequency and intensity of fires is spatially more heterogeneous 272 in the south than in central and northern Mexico (Galicia et al. 2015), but more precise data 273 are lacking. Fire regimes vary spatially and temporally, with low-intensity surface fires or 274 relatively frequent high-intensity fires or infrequent high-intensity fires (Rodríguez-Trejo 275 2008). Changes in extension, composition and distribution of oak and pine species in 276 response to fire are influenced by disturbance, climate variability and modern land use 277 (González-Espinosa et al, 1991; González-Tagle et al. 2011). Hence, tree dynamics are not 278 driven by large-scale fire dynamics since only $10 \%$ of fires occur in temperate forest; 279 however, fire is a local driver of tree dynamics in some regions of the country since it 280 creates space among individuals or stands for seed germination in the Sierra Madre 281 Oriental, Northern Mexico (González-Tagle et al. 2008). Tree mortality and species replacement in forests are markedly influenced by 283 natural disturbances other than fire. Gap dynamics is one of the major drivers of 284 regeneration in temperate forests but occurs mostly at a local level as a result of 285 environmental (physical, biological and resource) heterogeneity (González-Tagle et al. 286 2011). In southern Mexico, relatively shade-tolerant species such as $Q$. rugosa and $Q$. 
287

288

289

290

291

292

293

294

295

296

297

298

299

300

301

302

303

304

305

306

307

308

castanea grow better under nurse plants. In fact, it has been suggested that disturbance-free successional paths should lead to mature forests dominated entirely by shade-tolerant oak species (Farjon and Styles 1997). Nevertheless, pines can replace oaks in successional areas where oaks are exploited for firewood, thus inhibiting the dominance of shade-tolerant species (García-Barrios and González-Espinoza 2004). In the Baja California Sur region, disturbance patterns are associated with the occurrence of hurricanes. Arriaga (1988) reported that about $18 \%$ of the state's surface area had been affected by tree falls, which had led to high mortality (up to 334 individuals/ha) in the humid season. Unfortunately, species-replacement mechanisms in mature forests are still poorly understood. In northern Mexico a higher proportion of fires are initiated by lightning (Rodríguez and Fulé 2003; Fulé et al. 2011); however, Meunier et al. (2014) report that recruitment peaks in this region are more closely tied to the local processes of tree recruitment and seedling survival.

\section{Some emerging challenges in Mexican temperate forests}

Mexican temperate forests have been negatively affected by land-use change, poor tenure, illegal logging, unsustainable timber extraction and climate change (Table 2), all of which have considerably reduced their area and species composition (Rzedowski 1978; GómezPompa 1985; Masera et al. 1997; Challenger 1998). Some 40\% of the area originally covered by these ecosystems has been converted into agricultural fields and, more recently, into pasturelands for livestock ranching (Challenger 1998). Illegal logging is significant, accounting for 3-5 million $\mathrm{m}^{3}$ year ${ }^{-1}$ of the total production of 7 million $\mathrm{m}^{3}$ year ${ }^{-1}$ (Rzedowski, 1978; Gómez-Pompa 1985; Masera et al. 1997; Challenger 1998). It is now 
309

310

311

312 315 2008).

316

estimated that $40 \%$ of timber production in Mexico comes from illegal logging (World Forest Institute 2015). Together, land use change and illegal logging are responsible for endangering about $40 \%$ of the species of pines in Mexico (P. attenuata, $P$. caribaea, $P$. contorta, P. coulteri, P. culminicola, $P$. jaliscana, $P$. jeffreyi, $P$. johannis, $P$. martinezii, $P$. maximartinezii, P. monophylla, P. muricata, P. nelsonii, P. pinceana, P. quadrifolia, $P$. remota, $P$. rzedowskii, $P$. strobiformis and $P$. strobus) (Challenger 1998; Sánchez-González

\section{Forest communities and land tenure}

The type of forest tenure requires social organization and participation. For example, it has been argued that supervision of logging through community forest management and good social organization could avoid the severe deforestation of forests (Bray and Merino 2005). The sustainable use of forest resources can be achieved if communities 1) perceive that forest resources are economically viable, 2) exercise control over their use and 3) consider the long-term advantages of using renewable resources (Bray and Merino 2005; Merino-Pérez and Segura-Warnholtz, 2007).

For example, the communities of Nuevo San Juan Parangaricutiro in Michoacán and Ixtlán de Juárez in Oaxaca are good examples of forest sustainability. In each case, historical processes have generated political and social changes that have given rise to the emergence of a community-based company; this has the capacity to plan guidelines for managing the exploitation of their forests in balance with economic and social development. In Nuevo San Juan, for more than 20 years, the community has maintained a 
331 wide range of successful eco-businesses based on sustainable forestry, involving eco332 friendly production of furniture and resins, ecotourism, wood extraction through 333 agroforestry, and wildlife management (González-Carmona et al. 2014). In Ixtlán de Juárez, a well organized forestry company maintains tight controls over 335 the forest; a system of registration of timber produced and sold keeps track of the 336 transactions from forest to buyer (Matthews 2002). The distribution of economic benefits as 337 profit sharing is fair, and there is an explicit policy of increasing the added value of the 338 forestry production. Thus, community commitment to forest protection is broadly based on 339 the economic advantages to be derived from forest use. Interest in conservation is also 340 related to the domestic - often traditional - uses of the forest, and to the perception and 341 valuation of the "environmental services" forests provide; effective factors include the 342 concern to maintain water production, the perception of the forest as an inheritance for 343 coming generations, and the pure enjoyment of forest areas.

Two decades of community forest management have led, in some cases, to a more 345 balanced approach; in recent years forest management plans have been more varied, 346 promoting a mixture of intensive forestry, selective logging and conservation, depending on 347 a set of ecological variables (soils, slope, existing species, and closeness to water bodies). 348 These practices are consistent with the emergence of communities' territorial planning 349 practices and capacities (Bray and Merino 2005; Merino-Pérez and Segura-Warnholtz, 350 2007). On the basis of technical information about the different areas and resources they 351 own, but also of traditional knowledge and values, and the evaluation or their own needs, 352 communities decide the best uses to be given to the lands and resources they possess. 
354 similar fundamental conditions with Mexican forest regions, where forests constitute a key 355 element for community survival (Klooster 1999; Klooster and Masera 2000). Finally, the 356 same conceptual framework of sustainability is essential in the implementation of policies 357 that lead to the development and conservation of temperate forests, together with the 358 procurement of goods and services. It is necessary to promote change and direction for the 359 implementation of sustainable forest management, in order to meet the needs of social 360 groups living on the timber and non-timber forest products, as well as the needs of the 361 forest industry and the regional and national economy.

\section{Current Forest Management} seeds, roots and medicinal plants), the local extinction of commercially valuable species and a loss of diversity (Table 2). Furthermore, the use of species of pines, particularly the uncontrolled extraction of seeds of $P$. maximartinezii for sale in national and international markets, threatens their natural regeneration and distribution (López-Mata 2001). The use

371 of traditional timber harvesting techniques negatively affects soil fertility and vegetation

372 structure (Table 2). For example, Nájera-Luna et al. (2011) have shown that for every $1 \mathrm{~m}^{3}$ 373 of timber harvested, $0.481 \mathrm{~m}^{3}$ of soil is removed, and this has implications for soil fertility 374 and limits the potential future regeneration of timber species (Nájera-Luna et al. 2011). 
375 This is accompanied by changes in the total soil carbon concentration, from $4.7 \mathrm{~kg} \mathrm{~m}^{-2}$ in

376 the old-growth forest to $3.6 \mathrm{~kg} \mathrm{~m}^{-2}$ in thinned stands in Sierra Norte of Oaxaca (Saynes et 377 al. 2012).

Disruption of key natural ecosystem processes reduces forest adaptability and

379 resilience (Table 2). For example, intense and recurrent human-induced disturbances reduce 380 the diversity of disturbance-sensitive species; however, the occurrence of relatively 381 frequent low-intensity fires is believed to be part of the processes of these forests 382 (González-Rosales and Rodríguez-Trejo, 2004). In south-eastern Mexico, the coexistence 383 of Pinus and Quercus species is often associated with low-intensity disturbances (selective 384 timber extraction, firewood extraction and cattle grazing). Early-successional species are 385 used for fuel, whereas late-successional species are used for timber (González-Espinosa et 386 al. 1991; Galindo-Jaimes et al. 2002). Asbjornsen et al. (2004) reported that coexistence 387 patterns of Pinus and Quercus seedlings are regulated by a synergic interaction between 388 extreme events (droughts) and fragmentation. Each genus depends on the presence of 389 shrubs to facilitate colonization in the presence of drought, but pines are the more efficient 390 colonizers in highly fragmented landscapes thanks to their ability to rapidly use available 391 resources (Asbjornsen et al. 2004).

Mexico has used two major approaches for managing its temperate forests. First, the 393 Mexican Method of Irregular Forestry Development (MMOBI) is based on selective 394 logging, with cut intensity varying according to the current increase in volume of each 395 stand and with a fixed cutting cycle, respecting the maximum cut of $30-40 \%$ in stocks and a 396 minimum cutting diameter (30 cm for pine) (Zerecero and Pérez 1981; Pineda and 
397 Sánchez-Velásquez 1992; Gadow et al. 2004). The aim of the method is to modify the 398 characteristics of forests to obtain a balanced composition of age classes in stands while 399 conserving forest density. Application of MMOBI has resulted in a reduction in stocks of 400 shade-intolerant pines and replacement by the more shade-tolerant oaks and other 401 hardwoods (Hernández-Díaz et al. 2008). Second, the Forestry Development Method 402 (MDS) aims to convert irregular forests with little pine regeneration to pine-dominated 403 forests through the creation of large gaps, shelterwood or clear cutting followed by planting 404 of a few commercial pine species. This approach has greatly simplified both the 405 composition and structure of many Mexican temperate forests (Zerecero and Pérez 1981; 406 Negreros and Snook 1984; Hernández et al. 1996). Recently, many ejidos receive some sort 407 of financial support from CONAFOR or Commission of Natural Protected Areas 408 (CONANP) for conservation projects, specifically from Mexico's payments for ecosystem 409 services programs (PES). However, many pine forests in Mexico remain devoid of any 410 management.

Oaks are rather shade-tolerant, so they can establish successfully in small gaps

412 created by selective logging. Moreover, oaks can re-sprout from stumps left after cutting or 413 burning (Jardel 1985; Negreros and Snook 1984; Jardel-Peláez et al. 2004; Lara-González 414 et al. 2009). In undisturbed mixed oak-pine forests, successional processes proceed from 415 early pine-dominated stages to late stages where oak is dominant. This process is being 416 accelerated by the effect of selective logging (Table 2) (Negreros and Snook 1984; Jardel417 Peláez et al. 2004). Therefore, the use of selective logging as a forest management method 418 is ineffective for maintaining the mixed character of these forests (Negreros and Snook 419 1984; Pineda and Sánchez-Velásquez 1992). In Mexico, the current sylvicultural treatments 
420 have been applied without a good knowledge of the biology and growth patterns of the

421 specific species exploited (Zerecero and Pérez 1981; Islas et al. 1988). Only a few

422 sylvicultural approaches have been used in the temperate forest of Mexico, mainly selective

423 and selection cuts, and this has greatly limited the range of ecological conditions (soil type,

424 topography, and altitude) found in the forest (Table 2) (Negreros and Snook 1984; Pineda

425 and Sánchez-Velásquez 1992; Jardel-Peláez et al. 2004; Guerra et al. 2007).

426

427 Climate Change and Forest Management

Climate change, too, can affect forest composition, by altering growth, colonization and successional patterns (Table 3). Mexican temperate forests are among the ecosystems most vulnerable to climate change, at both the ecosystem (Villers-Ruíz and Trejo-Vázquez

431 1998) and species levels (Gómez-Mendoza and Arriaga 2007; Galicia et al. 2015).

432 Evidence comes from experimental studies and species modelling under various climate433 change scenarios. Global models suggest that temperate forests will be displaced under 434 conditions of climate change (Villers-Ruíz and Trejo-Vázquez 1998), creating new 435 assemblages of species. Gómez-Mendoza and Arriaga (2007), using a statistical 436 downscaling process of the Special Report on Emission Scenarios (SRES) A1 (severe) and 437 B2 (conservative) scenarios, concluded that species of both Pinus and Quercus differ in 438 their sensitivity to climate change (Table 3, Figure 3). They also suggested that species with 439 a wider geographical range are not less vulnerable to climate change, because the change in 440 a species' geographical range seems to be associated with its own climatic tolerance. For 441 example, $P$. rudis, $P$. chihuahuana, $P$. culminicola, $Q$. peduncularis and $Q$. sideroxyla- 
442 which currently occur in semi-cold, semi-humid climates - are highly vulnerable to climate 443 change, as suggested by reductions of $30-45 \%$ in their geographical ranges by the year 4442050 under the scenarios analysed. More recent studies (Himmelsbach et al. 2010; 445 Himmelsbach et al. 2012) concluded that P. pseudostrobus is among the Mexican tree 446 species most vulnerable to climate change, particularly in the central-north region (Table $4473)$. temperature and low rainfall would become more frequent at high-elevation sites, negatively affecting both tree species composition and recruitment. New climatic 451 conditions in high-elevation zones might reduce frost events, which would favour the 452 upward migration of low-elevation species (Table 3, Figure 3). By contrast, high-elevation 453 species such as $P$. hartwegii would be more prone to local extinction since they would not 454 be able to migrate further up in response to climate change. Such distributional shift of 455 species might favour the migration of oak forests towards higher elevations. Zacarías456 Eslava and Del Castillo (2010) suggested that, at the foothills of mountains, oak forests 457 might adapt better than pines to climate change. In addition, in several parts of the world, 458 human activities and climate factors associated with climate change have modified fire 459 regimes. The risk of fires in Mexico has been augmented in recent years by climate change. 460 Fire is closely associated with the negative rainfall anomalies now occurring in most parts 461 of northern Mexico and southern United States of America (Fulé et al. 2012; Galicia et al. 462 2015). A similar correlation between exceptionally dry periods, such as was caused by 463 ENSO in 1998, and exceptionally severe fire seasons has been clearly established for 464 Indonesia, Africa, and Central and South America. So there is an increasing consensus 
465 worldwide on the need to develop novel forest management strategies based on scientific

466 knowledge to improve the resilience and adaptability of ecosystems and human well-being

467 under the new conditions of rapid global change (Galicia et al. 2015).

\section{Forest management recommendations: toward a new conceptual framework}

471 are necessary, with restoration of natural forests, community-based forestry uses, 472 agroforestry, urban forestry, and management of international forest amenities, these 473 proposals have not been implemented. Mendoza et al. (2005) propose an approach to 474 landscape management. Since 2005, forest planning has implemented a new sylvicultural

475 regime - one designed to transform current stand structures back to those that existed before 476 timber-oriented forest management in the region. As discussed, current Mexican forest 477 management approaches are still rooted in the traditional narrow timber-based approach 478 that has proven inadequate for addressing current and emerging challenges to forest 479 ecosystems. This traditional approach to production forestry was developed to ensure a 480 sustained yield of timber products, disregarding the natural processes that have created and 481 maintained the diversity of structure, function and species as found in the temperate forests 482 of Mexico (FAO 2005). In fact, few studies have documented the effects of such harvesting 483 on the structure and functioning of these pine and oak forest ecosystems (Saynes et al. 484 2012). However, Mexican temperate forests also being managed for other goods and 485 services in addition to timber management (CONAFOR 2010); but we know little about the 486 structural, biological and climatic complexity, as well as the complex successional 
487 processes that are typical of high-mountain temperate forests. We thus propose a new 488 conceptual framework to manage Mexican temperate forests that is more in line with (1) 489 the natural dynamics of these forests, (2) the rapidly changing global environmental, social 490 and economic conditions, and (3) the emerging complex-adaptive-system approach.

For Mexican temperate forests, the following features and functions should be 492 maintained as a priority: biodiversity, water capture, carbon storage, timber forest resources and non-timber forest resources (Galicia and Zarco-Arista 2014). To protect biodiversity and forest resources for the future, many forest regions in the world are now advocating forest practices that are emulating the natural disturbances that have created this diversity of forest structure and function in the first place (Harvey et al. 2002). This requires an understanding of the extent, intensity and frequency of past natural disturbances. However, 498 this approach may be insufficient since future social, economic and environmental 499 conditions are likely to differ from those in the past. A modification of this forest 500 management based on natural disturbance (Puettmann et al. 2009; Puettmann 2011; Messier 501 et al. 2013) entails complexity science. This approach still recognises the necessity to 502 maintain the diversity of structure, function and species naturally found in our forests 503 through a variety of forest harvesting approaches, but instead of looking toward past or 504 current forest conditions and focussing on specific stand structure and species composition, 505 it focuses on adapting the forest to future uncertain environmental conditions. The role of 506 the forest manager, then, is not to impose a strict predetermined structure or composition, 507 but rather to help the forest to change and adapt while maintaining the important structure 508 and function on which we depend. This seems particularly appropriate for temperate 509 Mexican forests because of the high number of oak and pine species adapted to varied 
510 environmental conditions. A general description of this approach can be found in Messier et 511 al. (2013).

513 functional TRIAD zoning (Seymour and Hunter 1999), as has recently been applied on a

514 large scale in central Québec (Messier et al. 2009). TRIAD zoning divides the landscape 515 under management into three zones: one dedicated to intensive forest production, one 516 strictly protected, and the third implementing more natural forestry practices with lower 517 impacts. Despite this division, these three zones must be planned and managed in a 518 coordinated effort to maintain a diverse, productive and adaptable forest. Both the intensive 519 and extensive forest management areas should be planned to maintain a continuous corridor 520 among protected areas to facilitate species movement and migration. Also, the intensive 521 management areas could grow tree species that are better adapted to future climatic 522 conditions, favouring the overall adaptability of the forest landscape. High timber 523 production could be achieved with fast-growing species, but such plantations should not 524 cover too large an area, and should be of as many different species as possible and/or of 525 mixed species (Paquette and Messier 2010).

\section{A complex adaptive system and zoning for Mexican temperate forest?}


532 Although some management is good and forward looking, the challenge is to develop a 533 more integrated and resilience-based approach to face the emerging challenges. We believe 534 that a zoning approach embedded within a complex-adaptive-system framework may better 535 achieve and maintain the varied objectives required of Mexican forests.

A first step would be to analyze the forest landscape in terms of its spatial 537 configuration, diversity of forest structure and composition, and diversity and spatial extent 538 of ownerships. This would determine where each of the three main forest management 539 zones could be allocated. In areas close to a well establish road system and a possible 540 market, a significant portion of the landscape could be allocated to intensive forest 541 production via plantations; these need not constitute a single species, since multi-species 542 plantations may offer greater productivity and resilience to known and unknown 543 disturbances (Paquette and Messier 2013). The mixtures of pine and oak species should be 544 chosen to produce high quality and quantity in both timber and various ecosystem services. 545 Some conservative migration could also be promoted along the altitudinal gradient to take 546 into consideration the changing climatic conditions. The advantages of mixed forest 547 plantations are the increase in productivity, improvement of soil fertility, increase of forest 548 resilience against pests, diseases and climatic anomalies, and the potential to generate a 549 much greater variety of ecosystem services (Paquette and Messier 2010). These plantations 550 could connect otherwise unconnected forest fragments and increase the diversity of key but 551 rare functional traits that may allow the extensively managed and protected forests to adapt 552 to global changes. 
554 may help to understand the capability of natural systems to adapt to global changes. For 555 example, in the mountainous regions of central Mexico, trial altitudinal and latitudinal

556 corridors could be created, and environments that could function as buffers against climate 557 change could be identified. Such areas could indicate how species are adapting to global 558 changes. These protected areas should be large enough to allow the greater natural 559 disturbances to occur without affecting the entire area and they should be evenly distributed 560 across the landscape (Margules and Pressey 2000). This pursues the objective of 561 maintaining the area of primary forests and of protected areas with multiple conservation 562 purposes. It is necessary to establish protected areas in Mexico that aim to preserve 563 biodiversity, functional attributes and ecosystem services while at the same time ensuring 564 the future forest composition in the face of climate change. A natural consequence of 565 conserving species richness is the maintenance of the ecologic and genetic diversity of pine 566 and oak species (with their different ecological tolerances, and morphological and 567 phenotypical variations); this can facilitate species persistence and the formulation of 568 strategies for the maintenance of populations to implement better forest management 569 strategies and restoration projects in the future. Genetic diversity is key for strategies to 570 adapt to climate change (Allen and Holling 2010; Vayreda et al. 2012; Tompkins and 571 Adger 2005). However, a better understanding of the autecology of the various pine and 572 oak species is also necessary, and the possibility of facilitating the migration of some key 573 tree species (Aubin et al. 2011) that could become threatened by a rapidly changing 574 environment should also be evaluated. 
576 variety of harvesting approaches so as to create a diversity of environmental conditions to 577 allow the forest to "experiment" with different structural and compositional conditions to

578 facilitate adaptation to the novel internal and external biotic and abiotic conditions created 579 by global changes. This is possible owing to the highly heterogeneous forest communities 580 that manage and live in the forests in this region, and the different forms of social 581 organization that can allow the establishment of spatially diverse forestry practices and 582 forest (control of small fires, logging, and conservation). Within- and between-stand 583 heterogeneity in ecosystem structure, composition and function can be favoured in order to 584 recreate natural variability in forest conditions and processes (Puettmann et al. 2009). 585 Forest harvesting should aim not only to replicate the diversity of past natural disturbances, 586 but also to experiment with new disturbances that might help to increase adaptability to 587 future environmental conditions. Once harvested, the forest should be allowed to recover 588 naturally and thereby eventually to develop novel structures and compositions that are 589 better attuned to the emerging environmental conditions. To implement such a management 590 framework in Mexican temperate forests, research should focus on the role that natural 591 disturbances have played in the development of the current diversity of tree species and 592 composition across the various regions where temperate deciduous forest occurs in Mexico. 593 This approach follows a multipurpose forestry objective aiming to meet the needs of as 594 many stakeholders as possible while considering the rapidly changing physical and 595 biological conditions of forests and the future uncertainty; a high diversity of conditions 596 must be maintained to facilitate the adaptation of forests to those new conditions. The 597 current situation of the temperate Mexican forests (few protected areas, low forest 
598 management intensity, a need to increase wood production, high tree species diversity and 599 rapid climate change) provides a near-perfect opportunity to implement a functional zoning 600 approach in conjunction with a complex adaptive system to ensure the future maintenance 601 of the variety of goods and services that this forest provides.

602

603

\section{Acknowledgements}

604 This work is part of the sabbatical residency of the first author at McGill University. 605 Leopoldo Galicia acknowledges CONACYT (Grant 150095) for academic support during 606 his sabbatical leave. Funds for this research were provided by PAPIIT-UNAM grant IN 607105712.

608

609

\section{References}

610 Aguirre-Gutiérrez, J. and Duivenvoorden, J.F. 2010. Podemos proteger especies en riesgo en áreas protegidas? Un estudio de caso del genero Pinus en México. Rev. Mex. Biodiv. 81(3): 875-882. within and high levels of genetic differentiation among populations of species of Abies from southern México and Guatemala. American Journal of Botany. 87: 362371. 
617 Allen, C.R. and C. Holling, 2010. Novelty, adaptive capacity, and resilience. Ecology and $618 \quad$ Society. 15(3): 24.

619 Arriaga, L. 1988. Natural disturbance and treefalls in a pine-oak forest on the Peninsula of 620 Baja California, Mexico. Vegetatio. 78: 73-79.

621 Arriaga-Cabrera, L., Aguilar, V. and Espinoza, J.M. 2009. Regiones prioritarias y 622 623 624 625 626 planeación para la conservación de la biodiversidad. Pages 433-457. Capital natural de México vol. II: Estado de conservación y tendencias de cambio. CONABIO, México, D.F.

Asbjornsen, H., Vogt, K.A. and Ashton, M.S. 2004. Synergistic responses of oak, pine and shrub seedlings to edge environments and drought in a fragmented tropical highland oak forest, Oaxaca, Mexico. Forest Ecology and Management. 192: 313-334.

Aubin, I., Garbe, C.M., Colombo, S., Drever, C.R., McKenney, D.W., Messier, C., Pedlar, J., Saner, M.A., Venier, L., Wellstead, A.M., Winder, R., Witten, E. and Ste-Marie, C. 2011. Why we disagree about assisted migration: Ethical implications of a key debate regarding the future of Canada's forests. Forestry Chronicle. 87(6): 755-765.

Ávila-Flores, D.Y., Pompa-García, M. and Vargas-Pérez, E. 2010. Análisis espacial de la ocurrencia de incendios forestales en el estado de Durango. Revista Chapingo. Serie Ciencias Forestales y del Ambiente. 16 (2): 253-260.

Bray, D.B. and Merino, L. 2005. La experiencia de las comunidades forestales en México. Instituto Nacional de Ecología (INE-SEMARNAT). 
637 Bréda, N., Huc, R., Granier, A. and Dreyer, E. 2006. Temperate forest trees and stands 638 under severe drought: a review of ecophysiogical responses, adaptation processes 639 and long-term consequences. Ann. For. Sci. 63: 625-644

640 Cavender-Bares, J. 2007. Chilling and freezing stress in live oaks (Quercus section 641 virentes): intra- interspecific variation in PS II sensitivity corresponds to latitude of 642 origin. Photosynthesis Research. 94: 437-453.

643 Cavender-Bares, J.A., González-Rodríguez, A., Pahlich, K. and Deacon, N. 2011. 644 Phylogeography and climatic niche evolution in live oaks (Quercus series virentes) 645 from tropics to the temperate zone, Journal of Biogeography. 38: 962-981.

646 Ceballos, G., Arroyo-cabrales, J. and Medellín R. 2002. The mammals of Mexico: 647 composition, distribution, and conservation status. Occasional Papers, Texas Tech $648 \quad$ University. 218: 1-27.

649 Challenger, A. 1998. Utilización y Conservación de los Ecosistemas Terrestres de México. 650 Pasado, Presente y Futuro, Comisión Nacional para el Conocimiento y Uso de la 651 Biodiversidad, México, D.F.

652 CONABIO. 2007. Mapa ANP para los análisis de vacíos y omisiones en conservación. 653 Comisión Nacional de Áreas Naturales Protegidas y Comisión Nacional para el 654 Conocimiento y Uso de la Biodiversidad, México.

655 CONAFOR. 2008. Anuarios estadísticos de la producción forestal. 
656 CONAFOR. 2010. Servicios Ambientales y Cambio Climático. Coordinación General de 657 Producción y Productividad. México.

658 CONAFOR. 2012. Base de datos Estadísticos. Consulta temática. Recursos forestales.

659 Delgado, P., Salas-Lizana, R., Vázquez-Lobo, A., Wegier, A., Anzidei, M., Alvarez-Buylla, 660 E.R., Vendramin, G.G. and Piñero, D. 2007. Introgressive hybridization in Pinus 661 montezumae Lamb. and Pinus pseudostrobus Lindl. (Pinaceae): morphological and 662 molecular (cpSSR) evidence. International Journal of Plant Sciences. 168: 861-875.

663 Delgado, P., Eguiarte, L.E., Molina-Freaner, F., Álvarez-Buylla, E.R. and Piñero, D. 2008. 664 Using phylogenetic, genetic and demographic evidence for setting conservation 665 priorities for Mexican rare pines. Biodiversity and Conservation. 17: 121-138.

666

667

668

669

670

671

672

673 Eguiluz, P.T. 1982. Clima y distribución del género Pinus en México. Ciencia Forestal. $38: 30-44$. 
675 Eguiluz-Piedra, T. 1985. Origen y evolución del género Pinus (con referencia especial a $676 \quad$ los pinos mexicanos). Dasonomia Mexicana. 6(3): 5-31.

677 FAO. 2010. Evaluación de los recursos forestales mundiales 2010: informe nacional 678 México. Departamento Forestal-FAO. Roma, Italia. Disponible en 679 http://www.fao.org/docrep/013/al567S/al567S.pdf.

680 Farjon, A. 1990. Pinaceae: drawings and descriptions of the genera Abies, Cedrus, 681 682 683 684 Farjon, A. and Styles, B.T. 1997. Pinus (Pinaceae). Flora Neotropica Monograph 75. New York, NY: The New York Botanical Garden.

685

Food and Agriculture Organization of the United Nations. 2005. "Primera revisión del 686 programa estratégico forestal 2025 y del programa nacional forestal 2001-2006.

Fulé, P.Z. and Covington, W.W. 1994. Fire-Regime Disruption and Pine-Oak Forest 689 Structure in the Sierra Madre Occidental, Durango, Mexico. Restoration Ecology. $2: 261-272$.

Fulé, P.Z. and Covington, W.W. 1996. Changing Fire Regimes in Mexican Pine Forests: Ecological and Management Implications. Journal of Forestry. 94: 33-38. 
694 Fulé, P.Z. and Covington, W.W. 1998. Spatial patterns of Mexican pine-oak forests under 695 different recent fire regimes. Plant Ecology. 134:197-209.

696 Fulé, P.Z. and Covington, W.W. 1999. Fire Regime Changes in La Michilía Biosphere 697 Reserve, Durango, México. Conservation Biology. 13:640-652.

698

699

700

701

702

703

704

705

706

707

708

709

710

711

712

713

Fulé, P.Z., Ramos-Gómez, M., Cortés-Montaño, C. and Miller. A.M. 2011. Fire regime in a Mexican forest under indigenous resource management. Ecological applications 21:764-75.

Fulé, P.Z., Crouse, J.E., Roccaforte, J.P. and Kalies, E.L., 2012. Do thinning and/or burning treatments in western USA ponderosa or Jeffrey pine-dominated forests help restore natural fire behavior? Forest Ecology and Management. 269: 68-81.

Gadow. K.V., Sánchez, S. and Aguirre, O.A. 2004. Manejo forestal con bases científicas. Madera y Bosques. 10(2): 3-16.

Galicia, L., Zarco Arista, A.E. and Messier, C. Multicriteria decision analysis for planning competitive, multipurpose sustainable forest management. unpublished manuscript.

Galicia, L., Gómez-Mendoza, L. and Magaña, V. 2015. Climate change impacts and adaptation strategies in temperate forests in central Mexico: a participatory approach. Mitigation and Adaption Strategies for Global Change. 20(1): 21-42.

Galicia, L. and Zarco-Arista, A.E. 2014. Multiple ecosystem services, possible trade-offs and synergies in a temperate forest ecosystem in Mexico: a review. International Journal of Biodiversity Science, Ecosystems Services \& Management. 10: 275-288. 
714 Galicia, L., Cuevas Fernández, M.L., González Ramírez, L. and Couturier, S. 2014.

715 Detección de cambio ambiental en selvas y bosques de México con percepción 716 remota: un enfoque multiescalar de espacio y tiempo. Interciencia. 39 (6): 368-374.

717 Galindo-Jaimes, L., González-Espinosa, M., Quintana-Ascencio, P.F. and García-Barrios, 718 719 720

721 722

723

724 725 726

727 728 729 730 L.E. 2002. Tree composition and structure of disturbed stands with varying dominance by Pinus spp. in the highlands of Chiapas, Mexico. Plant Ecology. 162: 259-272.

García-Barrios, L.E. and González-Espinosa, M. 2004. Change in oak to pine dominance in secondary forests may reduce shifting agriculture yields: experimental evidence from Chiapas, Mexico. Agriculture, Ecosystems and Environment. 102: 389-401.

González Elizondo, M.S., González Elizondo, J.A., Tena Flores, L., Ruacho-González, I. and López-Enríquez, L. 2012. Vegetación de la Sierra Madre Occidental, México: Una síntesis. Acta Botánica Mexicana. 100: 351-403.

Gómez-Díaz, J.D., Monterroso-Rivas, A.I., Tinoco-rueda, J.A., Toledo-Medrano, M.L., Conde-Álvarez C. and Gay-García, C. 2011. Assessing current and potential patterns of 16 forest species driven by climate change scenarios in Mexico. Atmósfera. 24(1): 31-52.

Gómez-Mendoza, L. and Arriaga, L. 2007. Modeling the effect of climate change on the distribution of oak and pine species of Mexico. Conservation Biology. 21: 15451555. 
734 Gómez Pompa, A. 1985. Los recursos bióticos de México (reflexiones). Alhambra 735 Mexicana, México.

736 González-Espinosa, M., Quintana-Ascencio P.F., Ramírez-Marcial, N. and Gaytán737 Guzmán, P. 1991. Secondary succession in disturbed Pinus-Quercus forest in the 738 highlands of Chiapas, México. Journal of Vegetation Science. 2: 351-360.

González-Rodríguez, A., Arias, D.M., Valencia, S. and Oyama, K. 2004. Morphological and RAPD analysis of hybridization between Quercus affinis and Quercus laurina (Fagaceae) two Mexican red oaks. American Journal of Botany. 91: 401-409.

González-Rosales, A. and Rodríguez-Trejo, D.A. 2004. Effect of crown scorch on diameter growth of Pinus hartwegii Lindl. at the Distrito Federal, Mexico. Agrociencia. 38: 537-544.

González Tagle, M. A., Himmelsbach, W., Jiménez Pérez, J. and Müller-Using, B. 2005. Reconstruction of fire history in pine-oak forest in the Sierra Madre Oriental, Mexico. Forstarchiv. 76:138-143

González-Tagle, M.A., Schwendenmann, L., Jiménez-Pérez, J. and Himmelsbach, W. 2007. Reconstrucción del historial de incendios y estructura forestal en bosques mixtos de pinoencino en la Sierra Madre Oriental./ Reconstruction of fire history and forest structure in mixed pine-oak forest in the Sierra Madre Oriental. Madera Bosques. 13(02): 51-63.

González-Tagle, M.A., Schwendenmann, L., Jiménez-Pérez, J. and Schulz, R. 2008. Forest structure and woody plant species composition along a fire chronosequence in 
755

756

757

758

759

760

761

762

763

764

765

766

767

768

769

770

771

772

773

774

mixed pine-oak forest in the Sierra Madre Oriental, Northeast Mexico. Forest Ecology and Management. 256: 161-167.

González-Tagle, M.A., Jiménez-Pérez, J. and Himmelsbach, W. 2011. Impact of firewood extraction on leaf area index and canopy openness in mixed pine-oak forests in northeast Mexico. Forstarchiv. 25(82): 20-25. doi:10.2376/0300-4112-81-20

Guerra, V., Carrillo, F., Acosta, M., Islas, F., Flores, E., Mallen, C. and Buendía, E. 2007. El manejo forestal en el estado de Tlaxcala. Una revisión del desarrollo de la silvicultura. Folleto Técnico No. 25, INIFAP / CIR-CENTRO. México.

Harvey, B.D., Leduc, A., Gauthier, S. and Bergeron, Y. 2002. Stand-landscape integration in natural disturbance-based management of the southern boreal forest. For. Ecol. and Manag. 155: 369-385

Hernández, A., Martínez, M., Vargas, J., Velázquez, A. and Ángeles, G. 1996. Características de los anillos y densidad de la madera a diferentes alturas del fuste en rodales aclareados de Pinus patula Schl. et Cham. Rev. Ciencia Forestal en México. 21(80): 39-55.

Hernández-Díaz, J.C., Corral-Rivas, J.J., Quiñones-Chávez, B., Bacon-Sobbe, J.R. and Vargas-Larreta, B. 2008. Evaluación del manejo forestal regular e irregular en bosques de la Sierra Madre Occidental. Madera y Bosques. 14, 25-41.

Himmelsbach, W., Garza, E.J., Rodríguez, H.G., González, M.A., Estrada, A.E. and. Aguirre, O.A. 2010. Site-conditions reflected by seasonal and diurnal leaf water 
775

776

777

778

779

780

781

782

783

784

785

786

787

788

789

790

791

792 793

794 potentials of four co-occurring tree species in the Sierra Madre Oriental, Mexico. Forstarchiv. 81: 110-117.

Himmelsbach, W. Treviño-Garza, E.J., González-Rodríguez, H., González-Tagle, M.A., Gómez Meza, M.V., Aguirre Calderón, O.A., Estrada-Castillón, A.E. and. Mitlöhner, R. 2012. Acclimatation of three co-occurring tree species to water stress and their role as site indicators in mixed pine-oak forests in the Sierra Madre Oriental, Mexico. European Journal of Forest Research. 131:355-367.

González-Carmona, E., Gasca-Moreno, E. and Heredia-Díaz, P. 2014. Cultura organizacional del sistema empresarial de la comunidad indígena de Nuevo San Juan Parangaricutiro: un manejo sustentable forestal. Revista Mexicana de Agronegocios. XVIII (35): 1023-1034.

Islas, G.F., Elizalde del Castillo, N. and Hernández, V. 1988. La silvicultura en los aprovechamientos maderables de la región central de México. Revista Ciencia Forestal. 63(13): 3-13.

Jardel, E.J. 1985. Una revisión crítica del Método Mexicano de Ordenación de bosques desde el punto de vista de la ecología de poblaciones. Ciencia Forestal. 10(58): 316.

Jardel-Peláez, E.J., Santiago-Pérez, A.L., Cortés Montaño, C. and Castillo Navarro, F. 2004. Sucesión y dinámica de rodales. Pages 179-203 in R. Cuevas Guzmán, and E. J. Jardel Peláez, editors. 
795 Klooster, D. 1999. Community forest management in Mexico: Can it reverse processes of 796 degradation. Land Degradation and Development. 10 (4): 363-379.

797 Klooster, D. and Masera, O. 2000. Community forest management in Mexico: Carbon 798 mitigation and biodiversity conservation through rural development. Global Environmental Change. 10 (4): 259-272.

800

801

802

803

804

805

806

807

808

809

810

811

812

813 Matthews, A.S. 2002. Mexican Forest history: Ideologies of State Building and Resource 814

Lara-González, R., Sánchez-Velásquez, L.R. and Corral-Aguirre, J. 2009. Regeneration of Abies religiosa in canopy gaps versus understory, Cofre de Perote National Park, México. Agrociencia. 43: 739-747.

López-Mata, L. 2001. Proteins, amino acids and fatty acids composition of nuts from the Mexican endemic rarity, Pinus maximartinezii, and its conservation implications, Interciencia. 26(12): 606-610

Manzo-Delgado, L., Sánchez-Colón, S. and Álvarez, R. 2009. Assessment of seasonal forest fire risk using NOAA-AVHRR: a case study in central Mexico. International Journal of Remote Sensing. 30: 4991-501.

Margules, C. and Pressey, R. 2000. Systematic conservation planning. Nature. 405: 243253.

Masera, O., Ordoñez, M.J. and Dirzo, R. 1997. Carbon emissions from Mexican forest current situation and long term scenarios. Climatic Change. 35: 265-295. 
815 Mendoza, M.A., Fajardo-Aceves, J.J. and Zepeta, J. 2005. Landscape based forest 816 management- a real world case study from Mexico. Forest Ecology and Management. 209 (1-2): 19-26

Merino-Pérez, L. and Segura-Warnholtz, G. 2007. Las políticas forestales y de conservación y sus impactos en las comunidades forestales en México. En: David Barton-Bray, D., Merino Pérez, L., y Barry, D. (eds). Los bosques comunitarios de México: Manejo sustentable de paisajes forestales. pp 77-98.

822

823

824

825

826

827

828

829

830

831

832

Messier, C., Tittler, R., Kneeshaw, D.D., Gélinas, N., Paquette, A., Berninger, K., Rheault, H., Meek, P. and Beaulieu, N. 2009. TRIAD zoning in Quebec: Experiences and results after 5 years. Forestry Chronicle. 85: 885-896.

Messier, C., Puettmann, K., Chazdon, R., Andersson, K.P., Angers, V.A., Brotons, L., Filotas E., Tittler, R., Parrott, L. and Levin, S.A. 2015. Stewardship of forests as complex adaptive systems in an uncertain world. Conservation Letters.

Messier, C., Puettmann, K. and Coates, D. 2013. Managing forests as Complex Adaptive Systems: Building Resilience to the Challenge of Global Change. New York, NY: Routlegde.

Meunier, J., Brown, P.M. and Romme, W.H. 2014. Tree recruitment in relation to climate and fire in northern Mexico. Ecology. 95(1): 197-209.

Molina-Freaner, F., Delgado, P., Piñero, D., Pérez-Nasser, N. and Alvarez-Buylla, E. 2001. Do rare pines need different conservation strategies? Evidence from three Mexican species. Canadian Journal of Botany. 79: 131-138. 
836 Moreno-Letelier, A. and Piñero, D. 2009. Phylogeographic structure of Pinus strobiformis

837

838

839

840

841

842

843

844

845

846

847

848

849

850

851

852

853

854
Engelm. across the Chihuahuan Desert filter-barrier. Journal of Biogeography. 36: $121-131$.

Nájera-Luna, J.A., Aguirre-Calderón, O.A., Treviño-Garza, E.J., Jiménez-Pérez, J., JuradoYbarra, E., Corral-Rivas, J.J. and Vargas-Larreta, B. 2011. Tiempos y rendimientos del aserrío en la región de El Salto, Durango, México. Revista Chapingo, serie ciencias forestales y del ambiente. 17(2):199-213.

Negreros, P. and Snook, L. 1984. Análisis del efecto de la intensidad de corta sobre la regeneración natural de pinos en un bosque de pino-encino. Ciencia Forestal. 9(47): $48-61$.

Nixon, K.C. 1993. The genus Quercus in Mexico. in: Ramamoorthy, T.P., R. Bye, A. Lot and J. Fa (eds.). Biological Diversity of Mexico: Origins and Distribution. Pp. 447458. Oxford University Press, Oxford.

Paquette, A. and Messier, C. 2010. The role of plantations in managing the world's forests in the Anthropocene. Front Ecol Environ. 8: 27-34.

Paquette, A. and Messier, C. 2013. Managing tree plantations as complex adaptive systems. In: Messier C, Puettmann K and Coates D. (Eds.). Managing forests as Complex Adaptive Systems: Building Resilience to the Challenge of Global Change. New York, NY: Routlegde. 
855 Parraguirre-Lezama, C., Vargas-Hernández, J.J., Ramírez-Vallejo, P., Azpíros-Rivero, H.S. 856 and Jasso-Mata, J. 2002. Estructura de la diversidad genética en poblaciones 857 naturales de Pinus greggii Engelm. Revista Fitotecnia Mexicana. 25: 279-279.

858 Perry Jr, J.P. 1991. The Pines of Mexico and Central America. Timber Press, Oregon, $859 \quad$ USA. 231 p.

860 Pineda, M.R. and Sánchez-Velásquez, L.R. 1992. Efecto de la corta selectiva sobre la 861 estructura de un bosque de pino- encino. Tiempos de Ciencia. 27: 69-77.

862 Poulos, M.H., Goodale, V.M. and Berlyn, G.P. 2007. Drought response of two Mexican 863 864 oak species Quercus lacey and Q. sideroxyla (Fagaceae), in relation to elevation position. Am. J. Bot. 94(5): 809-818.

865 Puettmann, K. 2011. Silvicultural challenges and options in the context of global change: 866 867 "simple" fixes and opportunities for new management approaches. J. of Forestry. 109 (6): 321-331.

868 Puettmann, K., Coates D. and Messier, C. 2009. A critique of silviculture: managing for 869 complexity. Island Press, Washington, $200 \mathrm{p}$.

Ramírez-Herrera, C., Vargas-Hernández, J.J. and López-Upton, J. 2005. Distribución y 871 conservación de las poblaciones naturales de Pinus greggii. Acta Botánica. 72: 1-

872 16. 
873 Richardson, D.M., Rundel, P.W., Jackson, S.T., Teskey, R.O., Aronson, J., Bytnerowicz, 874 A., Wingfield, M.J. and Proches, S. 2007. Human Impacts in Pine Forests: Past, 875 Present, and Future. Annu. Rev. Ecol. Evol. Syst. 38: 275-97.

876 Rodríguez Trejo, D.A. and Fulé, P.Z. 2003. Fire ecology of Mexican pines and a fire 877 management proposal. International Journal of Wildland Fire. 12(1): 23-37.

878 Rodríguez-Trejo, D.A. and Myers, R.L. 2010. Using oak characteristics to guide fire 879 880

881 882 883 884 885 886 887 888 889 890 891 regime restoration in Mexican pine-oak and oak forests. Ecological Restoration. 28(3): 304-323.

Rodríguez-Trejo, D.A. 2008. Fire regimes, fire ecology, and fire management in Mexico. AMBIO: A Journal of the Human Environment. 37: 548-556.

Rodríguez-Banderas, A., Vargas-Mendoza, C.F., Buonamici, A. and Vendramin, G.G. 2009. Genetic diversity and phylogeographic analysis of Pinus leiophylla: a postglacial range expansion. Journal of Biogeography. 36: 1807-1820.

Rzedowski, J. 1978. Vegetación de México.Limusa, México.

Rzedowski, J. 1993. Diversity and origins of the Phanerogamic Flora of Mexico. En: Ramamoorthy, T.P., R. Bye, A. Lot y J. Fa (Eds.). Biological diversity of Mexico. Origins and distribution. Oxford University Press. NuevaYork.

Sánchez-González, A. 2008. Una visión actual de la diversidad y distribución de los pinos de México. Madera y Bosques. 14 (1): 107-120. 
892 Sánchez-Velásquez, L.R., Pineda-López, Ma., R., Galindo-González, J., Zúñiga-González, 893 J.L. and Díaz-Fleischer, F. 2009. Opportunity for the study of critical successional 894 895 896 897

898

899

900

901

902

903 904

905 906

907 908 909 species). University of California Press. 282 p.

processes for the restoration and conservation of mountain forest: the case of Mexican pine plantations. Interciencia. 34(7): 518-522.

Sauer, J.D. 1988. Plant migration (the dynamics of geographic patterning in seed plant

Saynes, V., Etchevers, J.D., Galicia, L., Hidalgo, C. and Campo, J. 2012. Soil carbon dynamics in high-altitude temperate forests of Oaxaca (Mexico): thinning and rainfall effects. Bosque. 33(1): 3-11.

Seymour, R.S. and Hunter, Jr. M.L. 1999. New forestry in eastern spruce-fir forests: principle and applications to Maine. Maine, Agr. Exp. Sta. Misc. Pub. 716.36 p.

Tompkins, E.L. and Adger, W.N. 2005. Defining a response capacity for climate change, Environmental Science and Policy. 8: 562-571.

Valencia, S.A. 2004. Diversidad del género Quercus (Fagaceae) en México. Boletín de la Sociedad Botánica de México. 75: 33-53.

Vayreda, J., Martínez-Vilalta, J., Gracia, M. and Retana, J. 2012 Forest structure and management interact with recent changes in climate to determine the current forest carbon stock in Peninsular Spain. Global Change Biology. 18: 1028-1041

Villers-Ruiz, L. and Trejo-Vázquez, I. 1998. Climate Change on Mexican Forests and Natural Protected Areas. Global Environmental Change. 8: 141-157. 
912 Yocom, L. and Fulé, P.Z. 2012. Human and climatic influences on frequent fire in a high 913 elevation tropical forest. Journal of Applied Ecology. 49(6): 1356-1364.

914 Zacarías-Eslava, Y. and del Castillo, R.F. 2010. Comunidades vegetales templadas de la 915 Sierra Juárez, Oaxaca: pisos altitudinales y sus posibles implicaciones ante el 916 cambio climático. Boletin de la Sociedad Botánica Méxicana. 87: 13-28.

917 Zavala-Chávez, F. 1998. Observaciones sobre la distribución de encinos en México, 918 POLIBOTÁNICA Núm. 8:47-64.

919 Zavala Chávez, F. 2007. 2007. Guía de los encinos de la Sierra de Tepotzotlán, México. 920 Chapingo MEX: Universidad Autónoma de Chapingo.

921 Zerecero, G. and Pérez, V.M. 1981. El Manejo del Bosque y la Industria forestal en el norte 922 del país. Ciencia Forestal. 6(34): 30-44. 


\section{$923 \quad$ Figure captions}

924 Figure 1. Distribution of Mexican temperate forests. Letters mean geographical regions of 925 temperate forest: A Baja California, B Sierra Madre Occidental, C Sierra Madre Oriental; D 926 Eje Neovolcánico Transversal, and E Sierra Madre del Sur.

927 Figure 2. Altitudinal distribution of several pine and oak species in Mexican temperate 928 forest.

929 Figure 3. Hypothetical species migration driven by decreasing rainfall upward and 930 increasing temperature due to climate change. 


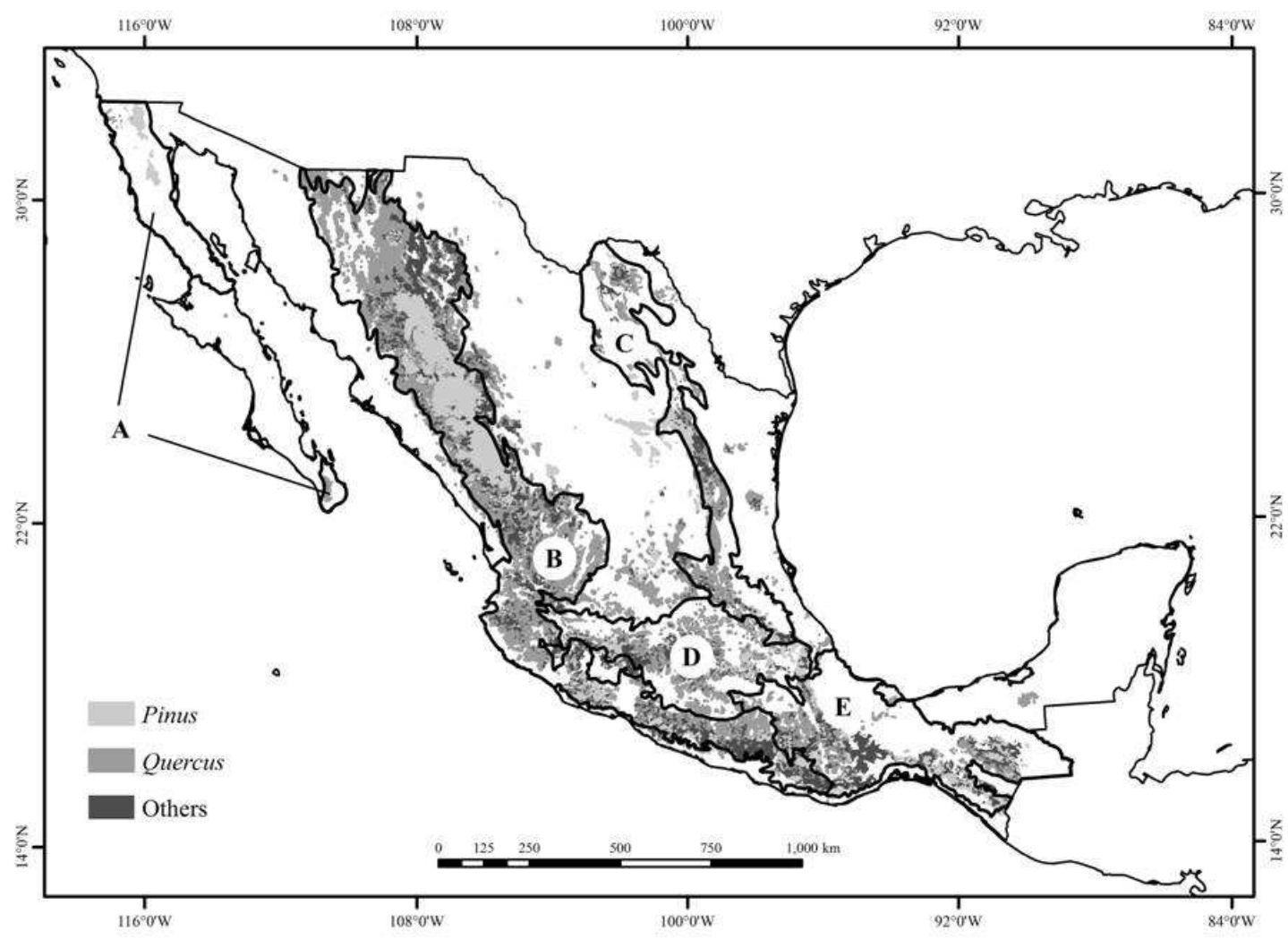




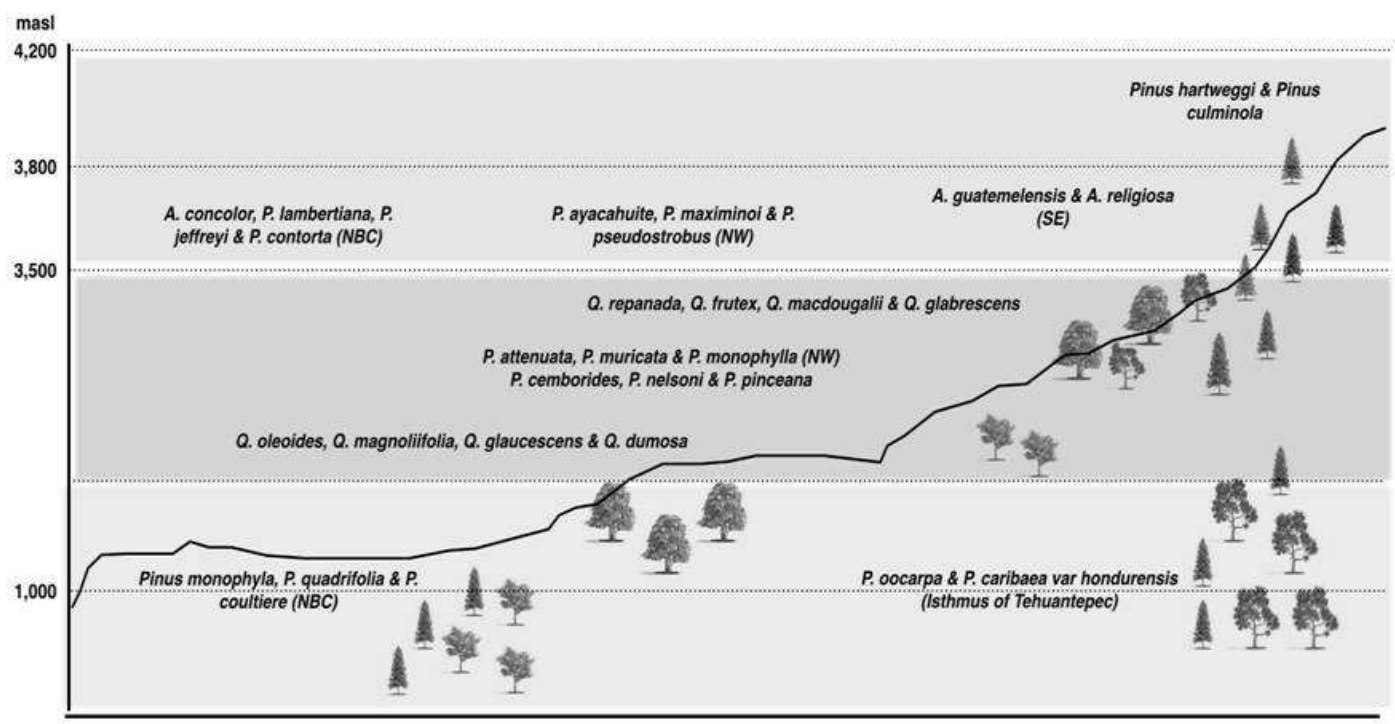




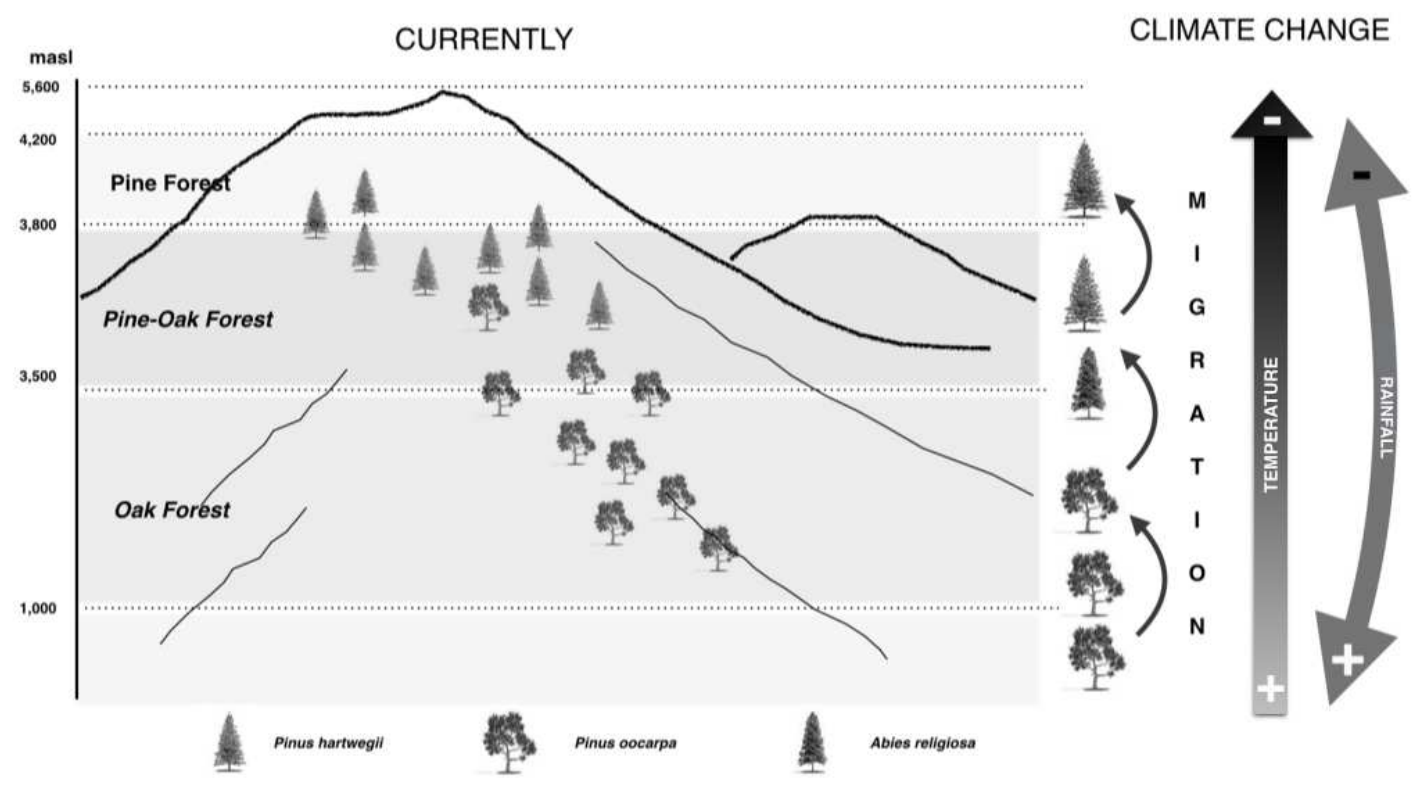


Table 1. Distribution of oak species in five regions of Mexico. E, species of the subgenus Erythrobalanus; L, species of the genus Lepidobalanus; and P, species of the genus Protobalanus.

\begin{tabular}{lccccc}
\hline Region & Species & Exclusive & E & L & P \\
\hline North-west & 47 & 16 & 19 & 25 & 3 \\
North-east & 45 & 8 & 17 & 28 & 0 \\
West & 53 & 1 & 25 & 28 & 0 \\
Central & 66 & 1 & 33 & 33 & 0 \\
South-east & 49 & 9 & 27 & 22 & 0 \\
\hline
\end{tabular}


Table 2. Biological legacies (Mature Forest), contemporary threats and effects on structure and function of Mexican temperate forest. For mature forest (Perry 1991; Rzedowski 1993; Farjon and Styles 1997; Aguirre-Planter et al. 2000; Molina-Freaner et al. 2001; Parraguirre-Lezama et al. 2002; Zavala-Chávez 2007; Dvorak et al. 2009; RodríguezBanderas et al. 2009; González-Elizondo et al. 2012). For land use change (GómezPompa 1985; Masera et al. 1997; Challenger 1998; Conabio 2007; Arriaga-Cabrera et al. 2009; Manzo-Delgado et al. 2009; Ávila-Flores 2010). For forest management (Negreros and Snook 1984; Pineda and Sánchez-Velásquez 1992; Asbjornsen et al. 2004; Jardel et al. 2004; Guerra et al. 2007; Nájera-Luna et al. 2011; Saynes et al. 2012). For climate change (Villers-Ruíz and Trejo 1998; Gómez-Mendoza and Arriaga 2007; Eslava and Del Castillo 2010; Gómez-Díaz et al. 2011; Galicia et al. 2015).

\begin{tabular}{|c|c|c|c|}
\hline Mature Forest & Land & Forest management & Climate Change \\
\hline $\begin{array}{l}\text { Altitudinal distribution. } \\
\text { Biodiversity (genetic, } \\
\text { species and ecosystems). }\end{array}$ & $\begin{array}{l}\text { Habitat and biodiversity } \\
\text { loss. } \\
\text { Fragmentation. }\end{array}$ & $\begin{array}{l}\text { Change in the } \\
\text { composition from pine to } \\
\text { oak with selection } \\
\text { methods. }\end{array}$ & $\begin{array}{l}\text { Change in the } \\
\text { distribution ranges of } \\
\text { species. }\end{array}$ \\
\hline $\begin{array}{l}\text { Functional redundancy. } \\
\text { Carbon pools. }\end{array}$ & $\begin{array}{l}\text { Change in species } \\
\text { composition. }\end{array}$ & $\begin{array}{l}\text { Dominance of pine } \\
\text { species with prescribed } \\
\text { burns. }\end{array}$ & $\begin{array}{l}\text { Dominance of pine } \\
\text { species less tolerant to } \\
\text { water deficit. }\end{array}$ \\
\hline $\begin{array}{l}\text { Connectivity. } \\
\text { Resistance and }\end{array}$ & $\begin{array}{l}\text { Reduction in above- and } \\
\text { below-ground carbon } \\
\text { pools. }\end{array}$ & $\begin{array}{l}\text { Loss of mechanisms of } \\
\text { stabilization of carbon } \\
\text { and nutrients. }\end{array}$ & $\begin{array}{l}\text { Migration of pine trees in } \\
\text { altitudinal gradient. } \\
\text { Biodiversity loss. }\end{array}$ \\
\hline \multirow[t]{4}{*}{$\begin{array}{l}\text { Spatial and temporal } \\
\text { heterogeneity. }\end{array}$} & $\begin{array}{l}\text { Loss of mechanisms of } \\
\text { stabilization of carbon } \\
\text { and nutrients }\end{array}$ & $\begin{array}{l}\text { Change in the light } \\
\text { environment and soil } \\
\text { temperature and soil } \\
\text { moisture. }\end{array}$ & $\begin{array}{l}\text { Increase in mortality of } \\
\text { mature trees through } \\
\text { drought. } \\
\text { Droughts. }\end{array}$ \\
\hline & $\begin{array}{l}\text { Loss of surface horizons } \\
\text { and soil structure }\end{array}$ & $\begin{array}{l}\text { Modification of } \\
\text { successional processes. }\end{array}$ & Pests. \\
\hline & . & Biodiversity loss. & $\begin{array}{l}\text { Extreme meteorological } \\
\text { events. }\end{array}$ \\
\hline & homogeneity & $\begin{array}{l}\text { Increase in the } \\
\text { dominance of few } \\
\text { species. }\end{array}$ & $\begin{array}{l}\text { Alteration of } \\
\text { hydrological regime. }\end{array}$ \\
\hline
\end{tabular}


Table 3. Sensitivity of species to climate change and fire (Villers \& Trejo 1998; mGómez-Mendoza \& Arriaga 2007; Gómez-Díaz et al 2011; Himmelsbach et al. 2010; Rodríguez-Trejo \& Myers 2010; Poulos et al. 2007; Yocom \& Fulé 2012).

\begin{tabular}{|c|c|c|c|c|c|}
\hline \multirow[b]{2}{*}{ Genus } & \multicolumn{3}{|c|}{ Climate Change } & \multicolumn{2}{|c|}{ Fire } \\
\hline & Sensitive & $\begin{array}{c}\text { Moderately } \\
\text { sensitive }\end{array}$ & No sensitive & Resistant & No resistant \\
\hline \multirow[t]{11}{*}{ Pinus } & P. oocarpa & P. patula & P. cembroides & P. hartwegii & P. reflexis \\
\hline & P. chihuahuana & P. durangensis & P. douglasiana & P. montezumae & $P$ arizonica \\
\hline & P. rudis & P. teocote & P. strobiformis & P. teocote & P. lumholtzi \\
\hline & P. hartwegii & P. ayacahuite & & P. culiminicola & P. strobiformis \\
\hline & & P. culminicola & & P. maximartinezii & \\
\hline & & P.leiophylla & & P. rzedowsky & \\
\hline & & P. herrerae & & P. cembroides & \\
\hline & & & & P. lagrunde & \\
\hline & & & & P. jaliscana & \\
\hline & & & & P. nelsonni & \\
\hline & & & & P. arizonica & \\
\hline \multirow[t]{9}{*}{ Quercus } & Q. crispipilis & Q. sideroxyla & Q. obtusata & Q. ryshophylla & \\
\hline & Q.peduncularis & Q. mexicana & Q. durifolia & Q. laceyi & \\
\hline & Q. acutifolia & Q. eduardii & Q. segoviensis & Q. macrophylla & \\
\hline & & Q. castanea & Q. elliptica & Q. chapmanni & \\
\hline & & Q. laurina & Q. scytophylla & Q. crassipes & \\
\hline & & Q. rugosa & Q. laeta & Q. crassifolia & \\
\hline & & Q. magnoliifolia & & Q. rugosa & \\
\hline & & Q. crassifólia & & Q. laeta & \\
\hline & & & & Q. obtusata & \\
\hline
\end{tabular}


